Western North American Naturalist 70(4), (C) 2010, pp. 425-436

\title{
RETROSPECTIVE EVALUATION OF THE EFFECTS OF HUMAN DISTURBANCE AND GOLDFISH INTRODUCTION ON ENDANGERED PAHRUMP POOLFISH
}

\author{
James E. Deacon ${ }^{1}$ and Joshua E. Williams ${ }^{2}$
}

\begin{abstract}
Life history data for Pahrump poolfish (Empetrichthys latos latos) collected from 1937 to 1975 were organized and analyzed to improve our understanding of changes caused by human habitat disruption and introduced goldfish (Carassius auratus) at Manse Spring, Nevada. Pahrump poolfish twice demonstrated their ability to recover numerically from a population crash. The first crash followed a November 1961 introduction of a few goldfish and subsequent removal of vegetation by local ranch children intent on turning Manse Spring into a swimming hole. The second crash followed another major habitat disturbance resulting from an unsuccessful attempt to eradicate goldfish in July 1967. Each crash (1962-1963 and 1967-1968) reduced the poolfish population to fewer than 50 adults and was followed by a population recovery to more than 1000 . Following the first habitat disruption, changes in poolfish population structure and poolfish diet were observed. These changes caused an increased mortality rate, resulting in disappearance or decline in relative abundance of larger poolfish size classes with a commensurate reduction in production of mature eggs by the population. We detected no additional changes in life history characteristics that could be associated with the second population crash and recovery. We concluded that removal of vegetation in the summer of 1962 and the more extreme habitat disruption and fish handling in June-July 1967 were human-induced pulse disturbances resulting in poolfish population crashes. We also concluded that the changes in poolfish life history characteristics resulted principally from press disturbances attributable to goldfish.
\end{abstract}

Key words: Pahrump poolfish, Empetrichthys latos latos, habitat disturbance, exotic fish, goldfish interaction, population structure, food habits, endangered species.

Resumen.-Los datos sobre la historia de vida del pez de poza Pahrump (Empetrichthys latos latos), recopilados entre 1937 y 1975, fueron organizados y analizados para ayudar a entender los cambios cusados por la perturbación antropogénica del hábitat y por la introducción del carpín dorado (Carassius auratus) a Manse Spring, Nevada. En dos ocasiones, los peces de poza Pahrump demostraron la habilidad de reponerse numéricamente después de descensos abruptos de la población. El primero fue en noviembre de 1961, después de la introducción de algunos carpines dorados y subsecuente remoción de vegetación por niños de ranchos locales con la intención de convertir Manse Spring en una poza para nadar. El segundo descenso ocurrió luego de otra perturbación de hábitat resultado de un intento fallido por erradicar el carpín dorado en julio de 1967. Cada descenso (1962-1963 y 1967-1968) redujo la población de peces de poza a menos de 50 adultos; y fue seguido por una recuperación de la población a más de 1000. Después de la primera perturbación del hábitat y descenso en la población de peces de poza, se observaron cambios en la dieta y la estructura de la población. Aparentemente, estos cambios ocasionaron un ascenso en la tasa de mortalidad, causando la desaparición o disminución de la abundancia relativa de peces de poza de clases de mayor tamaño, con una reducción proporcional en la producción de huevos maduros. No detectamos cambios adicionales en las características de historia de vida que pudieran estar asociados con el segundo descenso y recuperación de la población. Concluimos que la remoción de vegetación en el verano de 1962, y la aún mayor perturbación del hábitat y manejo de peces en junio/julio de 1967, fueron perturbaciones inducidas por el humano a modo de "pulso" que provocaron descensos de la población de peces de poza, y que los cambios en las características de historia de vida de los peces de poza resultaron principalmente de la presión por la alteración atribuida a los carpines dorados.

Pahrump poolfish (Empetrichthys latos latos) is the only surviving form of a genus with a Pliocene distribution extending from southern California to southern Nevada (Uyeno and Miller 1962). By the late 1950s, this genus was restricted to Manse Spring in Pahrump Valley,
Nevada (Soltz and Naiman 1978), and following a 1975 spring failure that dried its remaining natural habitat, has survived only as transplanted populations in 3 locations outside its historic range (Selby 1977, LaVoie 2004). Two subspecies, Empetrichthys latos concavus from

${ }^{1}$ Departments of Environmental Studies and Biological Sciences, University of Nevada, Las Vegas, NV 89154

${ }^{2}$ Department of Fisheries and Wildlife, Oregon State University, Corvallis, OR 97331. 
Raycraft Spring and Empetrichthys latos pahrump from Pahrump Springs disappeared in 1957 when the springs failed as a consequence of groundwater pumping (Soltz and Naiman 1978, Deacon 1979, Deacon et al. 2007). The only other species of the genus (Empetrichthys merriami), surviving until recently, disappeared from springs in Ash Meadows, Nevada, in the early 1950s apparently as a consequence of habitat alteration and from competition and predation by introduced freshwater crayfish (Procambarus clarkii), mosquitofish (Gambusia affinis), sailfin mollies (Poecilia latipinna), shortfin mollies (Poecilia mexicana), and bullfrogs (Rana catesbeiana) (Soltz and Naiman 1978, Miller et al. 1989, Scoppettone et al. 2005).

In the late 1960s, Minckley and Deacon (1968) projected failure of Manse Spring in fewer than 10 years on the basis of declining spring discharge. To prevent extinction of the last representative of Empetrichthys, the Nevada Department of Wildlife, in cooperation with the U.S. Fish and Wildlife Service and other federal and state agencies, transplanted Pahrump poolfish into 3 other fishless locations (and eventually a fourth) in Nevada. An initially successful transplant into Los Latos Pools on the Lake Mead National Recreation Area near Lake Mojave in June 1970 persisted for less than a decade. With management intervention, follow-up transplants into Corn Creek Springs on the Desert National Wildlife Refuge, Nevada (August 1971, April 1976), Shoshone Ponds Natural Area, and White Pine County, Nevada (March 1972), persist to the present. In June 1989, poolfish from Corn Creek Springs were used to establish a population in an irrigation reservoir at Spring Mountain Ranch State Park, Clark County, Nevada (LaVoie 2004). The failure of Manse Spring in August 1975 extirpated the remaining natural population of Empetrichthys sp. (Deacon et al. 2007).

During the 15 years prior to spring failure, Pahrump poolfish survived 2 nearly catastrophic bottleneck events (Deacon 1979). The first event was an introduction of 6 goldfish into Manse Spring in November 1961. By July 1962, the goldfish had reproduced. During summer 1962, local ranch children installed a diving board and removed submersed aquatic vegetation from the main spring pond in an effort to improve their swimming hole (Deacon et al. 1964). Subsequently, during winter 1962-1963, the poolfish population crashed to fewer than 50 individuals.
By fall 1963, the population had made a partial recovery to approximately 200 individuals, and by July 1967, the poolfish had reestablished a population of more than 1000 (Deacon 1979). The second event was a concerted effort from 29 June through 3 July 1967 to eradicate goldfish from the main spring pond. To accomplish this eradication, live poolfish were removed from the main spring pond and held in cages in the small upper connected spring. Initially, minnow traps were used to capture poolfish in deeper waters selectively, and dip nets were used in shallow waters. Following several days of trapping and dipnetting, repetitive seining was used to capture most goldfish and the few remaining poolfish. Goldfish were discarded on the banks along with vegetation and debris captured by the seine. On 3 July, rotenone was used with the intention of destroying any remaining fish in the pool and outflow; however, a few goldfish survived by remaining in the freshwater current at spring sources. Dynamite was used then in an unsuccessful effort to destroy the few goldfish still visible in the main spring pool. After rotenone was flushed from the system, approximately 1250 poolfish from cages in the upper spring were reintroduced into the main spring pool. Total lengths of 1089 of those poolfish were measured prior to returning them to the spring. Additionally, about 150 poolfish captured with a dip net (estimated at $<12 \mathrm{~mm}$ TL) were accidentally spilled back into the pond prior to being measured. By the end of summer 1967, the surviving adult goldfish had reproduced successfully (Deacon 1979). In a manner reminiscent of the population crash in 1962-1963, poolfish went through a severe population decline and by July 1968 reached another low of fewer than 50 individuals. The very low poolfish population persisted at least through January 1969, but by June 1970, a large poolfish population once again had been reestablished. It remained high until the August 1975 spring failure (Deacon 1979).

We present data on population structure, annulus formation, food habits, reproductive periodicity, and reproductive potential of the Manse Spring population of Pahrump poolfish, and we evaluate population responses of poolfish to habitat disturbances from humans and goldfish. The data we present were obtained from Manse Spring in June 1937 and from 1961 to 1968. The data will be useful in evaluating survival potential for $E$. $l$. latos in response to management 
activities required to maintain this endemic genus in the habitats to which it is now confined. The data will also be helpful in the attempt to differentiate between human- and goldfish-induced effects. Some data reported here were previously reported by Minckley and Deacon (1968), Deacon (1979), and Baugh et al. (1988); however, all data reported and analyzed here were taken directly from original field or laboratory notes.

\section{Methods \\ Study Site}

Manse Spring was the second largest spring in Pahrump Valley, Nevada, with a flow of 0.17 $\mathrm{m}^{3} \cdot \mathrm{s}^{-1}$ in 1875. Pahrump Spring, the largest spring in the valley, flowed $0.22 \mathrm{~m}^{3} \cdot \mathrm{s}^{-1}$ in 1875. Pahrump Spring, along with the much smaller Raycraft Spring, ceased flowing in the 1950 s as a result of groundwater pumping when 39-45 irrigation wells were operating in the valley. By 1961, flow of Manse Spring had been reduced to $0.05 \mathrm{~m}^{3} \cdot \mathrm{s}^{-1}$ and 55 irrigation wells were in operation (Minckley and Deacon 1968).

Prior to its failure in 1975, Manse Spring was an approximately triangular limnocrene, $9 \mathrm{~m}$ wide at the head, $2 \mathrm{~m}$ wide at the outlet, and $18 \mathrm{~m}$ long. A much smaller spring $46 \mathrm{~m}$ east of the main spring pool flowed in at its head. A shallow ditch extended 3-6 m southward from the main spring pool. The ditch had directed water southward out of the main spring pool earlier, but in June 1967, with no flowing water, the pool served as a backwater nursery and rearing area for newly hatched poolfish. Banks of the limnocrene were steep to nearly vertical. Water depth varied from about $3 \mathrm{~m}$ at the main spring source (north of the center near the widest part of the pool) to about $0.3 \mathrm{~m}$ at the outflow. The silt bottom was dominated by thick patches of watercress (Nasturtium sp.), stonewort (Chara sp.), and a fine-leaved pondweed (Potamogeton sp.); patches of green algae floated on the surface. Temperature was a relatively constant $24{ }^{\circ} \mathrm{C}$ (range 23.3-25.0 ${ }^{\circ} \mathrm{C}$ ). Oxygen concentration remained near saturation at about 8-9 ppm throughout most of the spring pool. Maximum dissolved oxygen recorded was 13 ppm (21 November 1964) and the minimum was $7.1 \mathrm{ppm}$ (23 January 1968). Water was clear, chalky blue, and alkaline. Water current was slow to absent in the pond and shallow ditch but became swift at the outflow. Poolfish occupied only the main spring pool, its outflowing stream, and the shallow ditch.

\section{Observations}

Collections and/or observations of poolfish at Manse Spring were made on 5 June 1937, at frequent intervals between 23 April 1961 and 23 July 1968, and intermittently until the spring went dry in August 1975. Except for the collections made in 1937 and 29 June-3 July 1967 (discussed above), fish were collected with plastic minnow traps lined with a 3.18 -mm plastic window screening. Captured fish were measured $(\mathrm{TL}=$ total length) before being returned to the spring pool. Samples were preserved in $10 \%$ formalin and transported to the University of Nevada, Las Vegas (UNLV), where they were washed with water and transferred to $70 \%$ ethanol. Subsequent observations and measurements included total and/or standard length $(\mathrm{mm}$; $\mathrm{SL}=$ standard length), body weight (nearest $0.0001 \mathrm{~g}$ ), ovary weight (nearest $0.0001 \mathrm{~g}$ ), numbers and sizes of ova, identification and enumeration of items occurring in the stomach and intestine, and measurement of distance from the focus of a scale to each apparent annulus and to the posterior scale margin. Throughout the 7year field investigation (1961-1968), 1879 poolfish were measured, excluding the nearly complete population sample of 1089 fish from June to July 1967. We also used the length data from the University of Michigan Museum of Zoology (UMMZ) collection of 64 fish captured on 5 June 1937. The largest poolfish (63 mm SL) in the 1937 collection was collected by hook and line, others with a $3.7-\mathrm{m}$ common sense minnow seine.

Most data were examined by dividing them into pre-goldfish (June 1937-November 1961) and post-goldfish (May 1962-July 1968) groups. The 12 poolfish collected on 30 November 1961 were included in the pre-goldfish group because only the 6 original adult goldfish appeared to be present in the spring pool on that date; residents informed us that the goldfish had been introduced very recently and had not been present on 27 October 1961, the date of our previous collection.

\section{Population Structure}

We examined population structure by separating length data into $10-\mathrm{mm}$ size classes $(0-9$, $10-19$, etc.) and calculating the percentage of the 
population within each increment. All poolfish lengths are reported as standard length. Conversion of total length to standard length was accomplished by measuring standard and total lengths of 219 poolfish collected from 5 June 1937 through 11 April 1963 and developing a direct conversion table from those data. The relationship of TL and SL for the 219 fish measured is described by the formula $\mathrm{SL}=$ $0.8507 \mathrm{TL}-1.5424, \mathrm{R}^{2}=0.9993$.

\section{Annulus Formation}

Scale samples were taken from the right side, posterior and dorsal to the pectoral fin, on 137 poolfish collected from 23 April 1961 through 11 April 1963, and from an additional 2 fish captured on 21 June 1964. Fish selected for sampling were not intentionally selected by either size or sex. Sex was determined for 118 of the 139 fish from which scales were taken. Consistency of annulus formation was examined by measuring multiple scales from 3 fish (1 female, 2 undetermined). Except for this examination of consistency, data on annulus formation are presented only for 112 female poolfish taken April 1961-1963.

\section{Food Habits}

Foods eaten by Pahrump poolfish were determined by examining stomach and intestinal contents of 115 poolfish collected April 1961-1963. Of these, 9 were males, 96 were females, and 10 were undetermined. Many were the fish from which scales had been removed, and we had no intention to select one sex over the other. Data on foods consumed are presented for all fish examined, but differences between sexes are not evaluated. Food items were identified and enumerated by placing contents in a petri dish on a grid pattern under a dissecting microscope. Items were identified to genus when possible and then grouped into major categories. Estimates of percent volume included bread used as bait in the traps because the bread could not always be differentiated reliably. Data are reported as frequency (percent of population examined containing the particular food item in the stomach or intestine), percent volume (mean visually estimated percent volume of the total food each category comprised in the stomach and intestine of fish utilizing the item), and $\mathrm{N}$ (mean number of items in the category occurring in the stomach and/or intestines of fish utilizing the item).

\section{Reproductive Periodicity}

Reproductive periodicity for 107 Pahrump poolfish was calculated by making 12 collections of 3-15 adult female poolfish at varying intervals from 7 October 1967 to 23 July 1968 (2 collections each in March, April, and November; no collections in June, August, or September). Fish were preserved, measured (SL), and weighed (nearest $0.0001 \mathrm{~g})$. Ovaries were excised and weighed (nearest $0.0001 \mathrm{~g}$ ), and maturity index (ovary weight/body weight) was calculated.

\section{Reproductive Potential}

Numbers of mature eggs produced, or reproductive potential, was determined by measuring and enumerating ova in the ovaries of 141 preserved poolfish 30-71 mm SL collected from April 1961 to April 1965. Mature eggs were absent in fish $<30 \mathrm{~mm} \mathrm{SL}$. Ova were measured with an ocular micrometer and classified as immature, mature, or atretic. Mature eggs had a transparent vitaline membrane and a yellow yolk, and were $\geq 1.2 \mathrm{~mm}$ in diameter. Immature eggs had no transparent membrane or yellow yolk and were $<1.2 \mathrm{~mm}$ in diameter. Atretic eggs were $\geq 1.2 \mathrm{~mm}$ in diameter but entirely opaque. Data were divided into April (peak spawning) and all other months (off-season), and mean number of mature eggs was calculated for each of the $10-\mathrm{mm}$ size classes $\geq 30 \mathrm{~mm}$ SL.

To estimate mature egg production of poolfish populations pre- and post-goldfish, we used length frequency data from the 1943 fish collected in 1937-1968. Fish were separated into 2 groups: 142 poolfish taken prior to establishment of goldfish (1937-1961), and 1801 poolfish taken after goldfish were established (19621968). These 2 groups were each further subdivided into April (peak spawning) and off-season subgroups. Based on the assumption that population structure for females did not differ from that calculated for Figures 2 and 3, mean number of mature eggs produced by each size class was multiplied by the percentage representation of each size class in each population subgroup. Results for each size class in each subgroup were summed and used to approximate pre- and postgoldfish reproductive potential.

\section{RESUlts}

\section{Population Structure}

Figure 1 compares population structure of the nearly complete population sample $(n=$ 


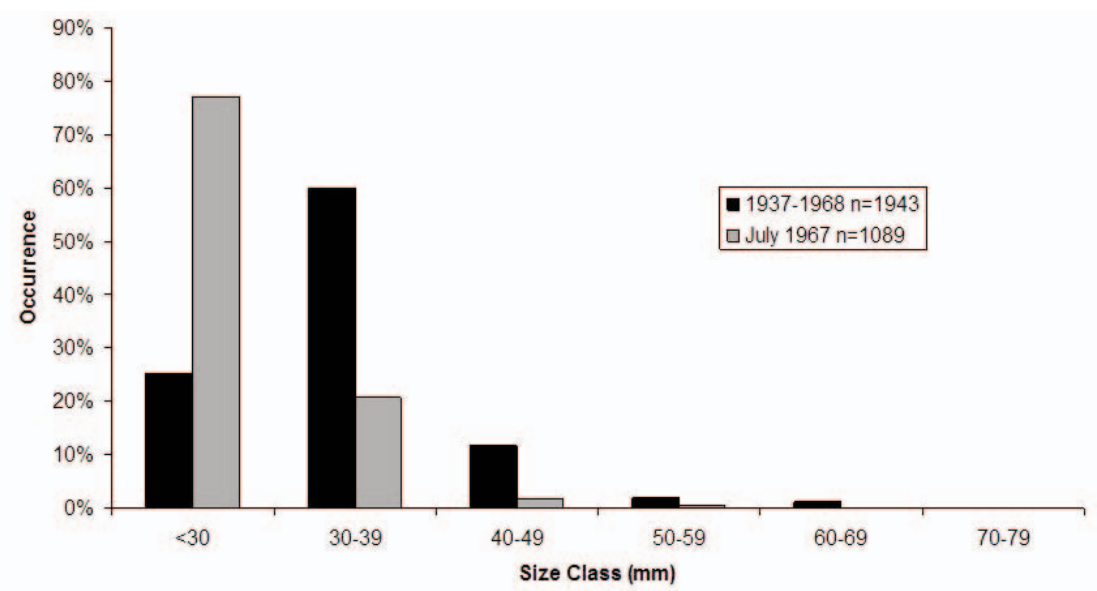

Fig. 1. Length frequency distribution of Pahrump poolfish collected from Manse Spring, Pahrump Valley, Nevada, on 29 June-3 July 1967 and from all other collections made in 1937-1968

1089) taken June-July 1967 with population structure illustrated by combining all other collections $(n=1943)$ taken from 1937 to 1968 . The population in June-July 1967 consisted of $77 \%$ of fish $<30 \mathrm{~mm}$ SL, while the sample from all other collections consisted of $75 \%$ of fish $\geq 30 \mathrm{~mm}$ SL. While this result may be partially attributable to sampling technique, it also suggests that larger fish were less dominant in the population in early July 1967, after goldfish had been established for about 5 years.

Figures 2 and 3 examine this question further by subdividing the 1943 poolfish collected from 1937 to 1968 into pre- and post-goldfish populations collected respectively in April (peak spawning season) and during all other times of the year (off-season). While pre-goldfish samples are small, the data suggest that in April, fish $\geq 40 \mathrm{~mm}$ SL (Fig. 2) and during the off-season, fish $\geq 60 \mathrm{~mm}$ SL (Fig. 3) were more prominently represented in the population.

\section{Annulus Formation}

Annuli were found on 72 (52\%) of the 139 Pahrump poolfish sampled 23 April 1961-21 June 1964. Six of the 118 poolfish for which sex was determined were males, and the remaining 112 were females. Sixty-three $(56 \%)$ of the females showed annuli. The largest female captured was $71 \mathrm{~mm} \mathrm{SL}$ and showed 3 annuli; the largest with 4 annuli was $66 \mathrm{~mm} \mathrm{SL}$. The smallest and largest with no annuli were 17 and $51 \mathrm{~mm}$ SL, respectively; the smallest with 1 annulus was $29 \mathrm{~mm}$ SL. No fish with 5 annuli were sampled.
Multiple scales from 3 different fish were examined in an effort to determine consistency of annulus formation (Table 1). Five scales from a single fish revealed 3 different patterns. The patterns for the remaining 2 fish were similar, but if interpreted as indicators of growth, they suggest very different growth rates for the 2 fish. This kind of pattern variability among scales from the same individual and between scales from different individuals suggests that while the annuli may indicate interruption of growth of a particular scale, they cannot be interpreted as indicators of growth rate of the fish from which they were taken.

Data on annulus formation are presented for females only (Table 2). These data show a postgoldfish increase in the proportion of the female population producing a first annulus, and smaller proportions forming 2 or more annuli. We interpret this result to suggest increased stress (higher proportions forming annulus one), and increased mortality rate (fewer surviving to form additional annuli). A fourth annulus was not identified on any female poolfish scale following establishment of goldfish.

\section{Food Habits}

Pahrump poolfish fed on a variety of aquatic insects, snails, other animal material, plant parts, and organic material, while ingesting inorganic (sand) material and bread (used as bait) in the process (Table 3). Items identified and grouped into each of these 6 food categories are shown in Table 4. 


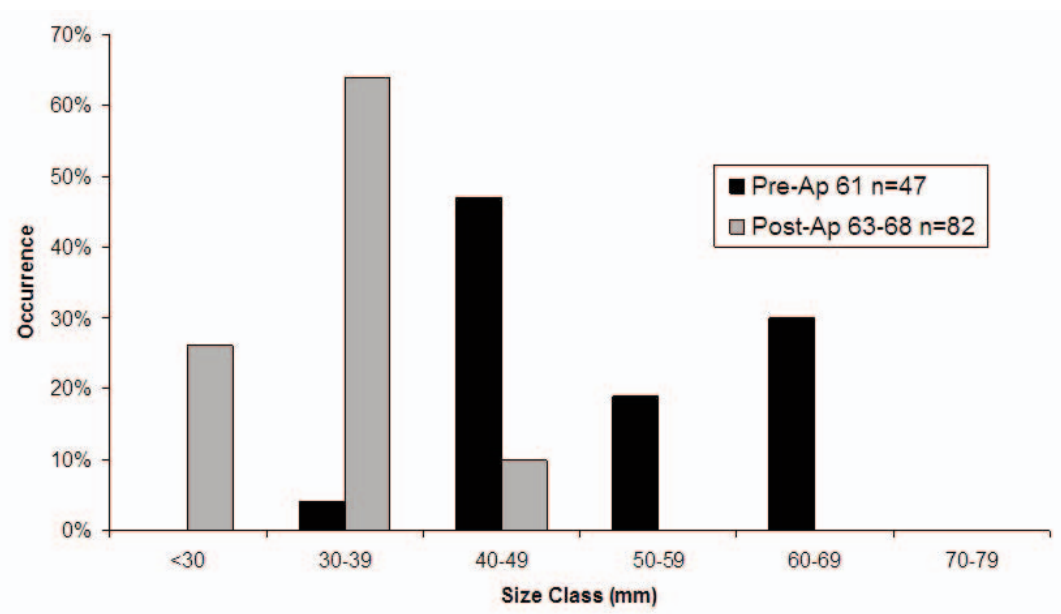

Fig. 2. Pre- (1961) and post-goldfish $(1963,1968)$ length frequency distribution of Pahrump poolfish from Manse Spring, Pahrump Valley, Nevada, in April (peak spawning).

Following the establishment of goldfish, the poolfish diet shifted from animals (primarily aquatic insects and snails) to plants. The percentage of the poolfish population ingesting plant material shifted from $28 \%$ to $68 \%$, while the average volume dropped from $71 \%$ to $57 \%$. The shift from aquatic insects exhibited very different characteristics than did the shift from snails. While the percentage of the poolfish population utilizing aquatic insects declined only slightly from $67 \%$ to $54 \%$, the average volume in the gut was reduced by half (from 59\% to $26 \%$ ) and average numbers dropped from 26 to 4 . In contrast, the percentage of the poolfish population utilizing snails dropped from $42 \%$ to $3 \%$, but when snails were present, their average volume in the gut more than doubled (from 26\% to 60\%), and average numbers were unchanged (Table 3 ).

At least one representative of one of the major food categories (snails) was undescribed when stomachs and intestines were examined. Since then, Hershler (personal communication [e-mail], 23 July 2008) has confirmed that the narrow spiral snail we identified in the poolfish guts almost certainly was Tryonia, while the snail identified as a squat spiral now has been described as Pyrgulopsis deaconi (Hershler 1998) (Table 4). Our original notes also identify a levo-spiral (possibly Physa) and a very tiny coiled snail (possibly Gyraulus) in the poolfish guts. The first 2 were common, and the latter 2 rare.

\section{Reproductive Periodicity}

Mean maturity index of Pahrump poolfish in Manse Spring in 1967-1968 was low in October and November, began to increase in December, was relatively high in March, May, and July, and reached a peak in April (Fig. 4). Mature eggs were identified in ovaries collected in JanuaryJuly 1961-1965, but not in August-December of those years.

\section{Reproductive Potential}

Females $<30 \mathrm{~mm}$ SL contained no mature eggs. Reproductive potential (mean number of mature eggs produced by each 10 -mm size class) in April for females $\geq 30 \mathrm{~mm}$ SL approximately doubles with each increasing 10 -mm size class (Table 5). While mature eggs are produced during the off-season, numbers are substantially lower than they are in April and do not increase with size, except for the smallest and largest size classes. The number and proportion of larger female poolfish in the population during April are therefore especially important determinants of reproductive potential.

\section{DISCUSSION}

Light and Marchetti (2007) present evidence suggesting that exotic species may be the primary driver of extinction and/or population decline for California freshwater fish, whereas the most damaging effect of habitat alteration is its tendency to support exotic species. Scoppettone et al. (2005) demonstrate that restoration 


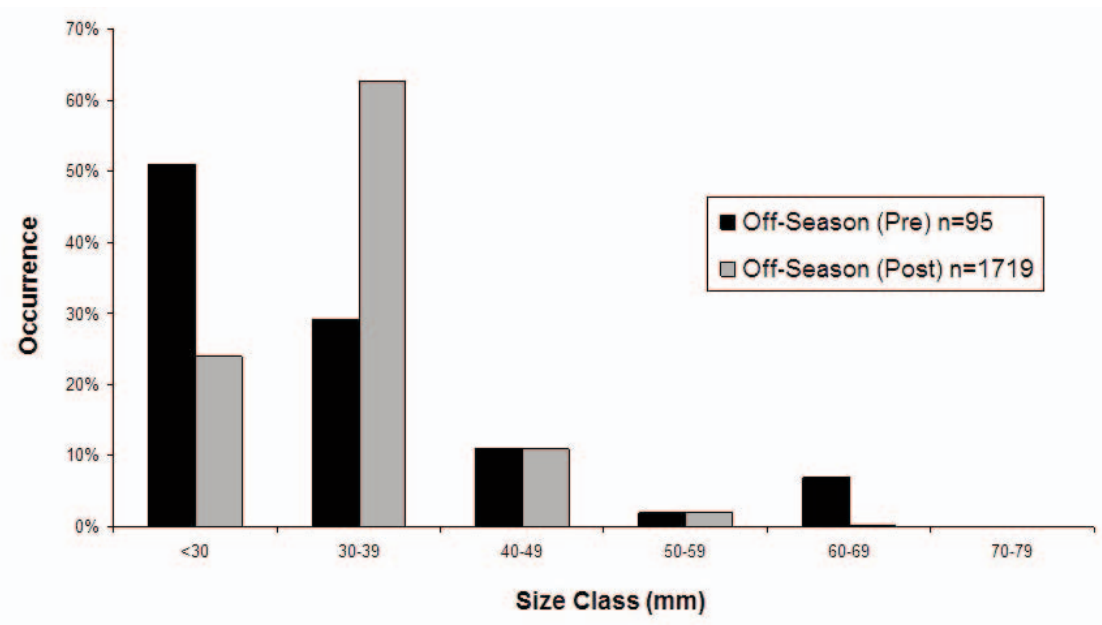

Fig. 3. Pre- (1937, 1961) and post-goldfish (1962-1968) length frequency distribution of Pahrump poolfish from Manse Spring, Pahrump Valley, Nevada, during months other than April (off-season).

of altered habitats can discourage dominance of nonnative fish while encouraging dominance of native species. Lake (2000) emphasizes the importance of understanding the temporal pattern of the intensity and duration of habitat disturbance. Our 1937-1975 observations at Manse Spring include 2 pulse disturbances (vegetation removal), and 2 press disturbances (goldfish populations). The timing of the disturbances and related evidence suggests that the press disturbances from goldfish populations were the primary causes of changes in poolfish life history characteristics, while the pulse disturbances were the proximate causes of the population crashes.

\section{Population Structure}

Less than 2 years following the establishment of goldfish, larger ( $\geq 60 \mathrm{~mm} \mathrm{SL}$ ), more-fecund poolfish disappeared from the population and had not reappeared by 1968 (Figs. 1-3). The largest poolfish collected from 1937 to 1968 was a $71 \mathrm{~mm}$ SL fish captured 24 July 1962 . The last poolfish $>60 \mathrm{~mm}$ SL was collected about 6 months later on 24 January 1963. In fact, $12.6 \%$ of the 207 fish collected and measured from June 1937 through January 1963 were $\geq 60 \mathrm{~mm}$ SL, while the largest of the 2825 fish captured and measured from April 1963 through July 1968 (including the 1089 fish collected on 28 June-3 July 1967) was $60 \mathrm{~mm} \mathrm{SL}$. The scarcity of larger fish is especially striking in April (Fig. 2 ), a time when it would have a major impact on the reproductive potential of the population.

\section{Annulus Formation}

Under the constant-temperature conditions at Manse Spring, formation of annuli on scales is unexpected. The variable patterns of annulus formation among scales on the same individual and between individuals (Table 1) suggests that annulus formation in this population may not be attributable to a synchronous environmental factor acting on the entire population at once. It likely reflects stress-related cessation of growth associated with phenomena such as goldfish interaction, reproduction, seasonal food scarcity, habitat disturbance, or similar factors that may influence individuals differently or at different times. Because of these potential variables and the Baugh et al. (1988) result that males are typically smaller than females, and because males are inadequately represented in our samples, data on annulus formation are presented only for females (Table 2). The increased proportion of female poolfish forming a first annulus following establishment of goldfish, the smaller percentages of the population apparently surviving to form subsequent annuli, and the fact that post-goldfish poolfish did not form a fourth annulus support evidence derived from population structure of a post-goldfish increase in mortality rates.

\section{Food Habits}

The poolfish diet quickly shifted from aquatic insects and snails (high energy density) to plants and organic materials (low energy density) 
TABLE 1. Measurements ( $\mathrm{mm}$ ) of multiple scales from 3 Pahrump poolfish and back-calculated size at annulus formation. SL = standard length; edge $=$ distance from focus to posterior margin of scale; $1(2,3)=$ distance from focus to annulus; SL-1 $(2,3)$ = back-calculated length. Sex undetermined for April samples; November fish was a female.

\begin{tabular}{lcccccccc}
\hline Date & SL & Edge & 1 & SL-1 & 2 & SL-2 & 3 & SL-3 \\
\hline 23 Apr 1961 & 67.0 & 2.1 & 1.4 & 44.7 & 1.7 & 54.2 & 1.9 & 60.6 \\
23 Apr 1961 & 67.0 & 2.0 & 1.3 & 43.6 & 1.7 & 57.0 & \\
23 Apr 1961 & 67.0 & 2.3 & 0.8 & 23.3 & 1.6 & 46.6 & 1.9 & 55.3 \\
23 Apr 1961 & 67.0 & 2.1 & 0.7 & 22.3 & 1.5 & 47.9 & 1.9 & 60.6 \\
23 Apr 1961 & 67.0 & 2.1 & 1.4 & 44.7 & 1.7 & 54.2 & 1.9 & 60.6 \\
23 Apr 1961 & 62.0 & 2.1 & 0.9 & 26.6 & 1.9 & 56.1 & \\
23 Apr 1961 & 62.0 & 2.2 & 0.9 & 25.4 & 2.0 & 56.4 & \\
30 Nov 1961 & 61.8 & 1.7 & 0.9 & 32.7 & 1.4 & 50.9 & \\
30 Nov 1961 & 61.8 & 1.8 & 1.0 & 34.3 & 1.5 & 51.5 & \\
30 Nov 1961 & 61.8 & 1.7 & 1.0 & 36.4 & 1.4 & 50.9 & \\
\hline
\end{tabular}

TABle 2. Distribution of annuli (percent) in female Pahrump poolfish before (1961, $n=31$ ) and after $(1962-1963, n=81)$ goldfish introduction.

\begin{tabular}{llllll}
\hline & \multicolumn{5}{c}{ Number of annuli } \\
\cline { 2 - 6 } & 0 & 1 & 2 & 3 & 4 \\
\hline 1961 & 61 & 39 & 26 & 6 & 6 \\
$1962-1963$ & 38 & 63 & 21 & 4 & 0 \\
\hline
\end{tabular}

following the establishment of goldfish and the removal of vegetation (Table 3). While a large percentage of the poolfish population continued to feed on aquatic insects, the relative volume of insects in the gut was reduced to about half the pre-goldfish level, and the average number of insects ingested declined from 26 to 4 . This pattern suggests that aquatic insects remained desirable food items but occurred at lower densities and were more difficult for poolfish to find.

The shift in utilization of snails followed a much different pattern. A much smaller percentage of the poolfish population apparently was able to find snails, but when snails were found, their relative volume doubled while the average number of snails ingested was unchanged. This suggests that snails remained abundant in scattered specific habitats (e.g., spring orifice or gravel substrate of the small stream entering the pond), and on occasions when poolfish encountered these pockets of snail abundance, they fed heavily. Selection of specific habitats in, or closely associated with a spring orifice, is common for springsnails (Sada 2008).

Our data do not permit a determination of whether the dietary shift persisted after April 1963. However aquatic insect and snail populations would be expected to decline following vegetation removal by ranch children during the summer of 1962. Goldfish may have a similar effect since they are known to increase turbidity by grazing on and uprooting aquatic macrophytes (Seaman 1979, Richardson et al. 1995). Moyle (2002) describes goldfish in California populations as omnivores that feed heavily on algae, zooplankton, aquatic macrophytes, and organic detritus, and only occasionally take insects and small fish. Jenkins and Burkhead (1993) describe the goldfish diet in Virginia as consisting of phytoplankton, macrophytes, aquatic insects, and small fishes. While turbidity, macrophyte and macroinvertebrate density, and distribution were not measured directly in Manse Spring, it is reasonable to suggest a causal relationship between the poolfish dietary shift and the goldfish population that became established in 1962 and persisted until the spring ceased flowing in 1975.

\section{Reproductive Periodicity}

The suggestion that poolfish in Manse Spring reproduce February-July, with a peak in April (Baugh et al. 1988) is supported by our maturity index data (Fig. 4) and reinforced by our observation that mature eggs were absent August-December 1961-1965. While mature eggs were present in fish collected in January through July, numbers of eggs consistently increased with increased fish size only in April. This emphasizes the importance of reproductive efforts in April.

In constant-temperature spring environments, restricted reproductive seasons are unusual (Espinosa 1968, Williams 1986, Riggs and Deacon 2002). In fact, Pahrump poolfish transplanted to other locations apparently adjust their spawning season to temperature conditions in the new habitat. Selby (1977) showed that this species in Corn Creek Spring, Las Vegas Valley, 
TABLE 3. Major food categories identified in stomachs and intestines of Pahrump poolfish from Manse Spring before (April through November 1961, $n=43$ ) and after (May through April 1962/63, $n=72$ ) goldfish establishment. \% $=$ percentage of population containing the food item; Vol. = estimated mean percent volume of total gut contents in fish containing the category; $n=$ average number of individuals in gut contents of fish containing the category.

\begin{tabular}{|c|c|c|c|c|c|c|c|c|c|c|c|c|c|c|c|}
\hline \multirow[b]{2}{*}{ Year } & \multicolumn{3}{|c|}{ Aquatic insects } & \multicolumn{3}{|c|}{ Snails } & \multicolumn{3}{|c|}{ Animal } & \multicolumn{2}{|c|}{ Plant } & \multicolumn{2}{|c|}{ Organic } & \multicolumn{2}{|c|}{ Other } \\
\hline & $\%$ & Vol. & $n$ & $\%$ & Vol. & $n$ & $\%$ & Vol. & $n$ & $\%$ & Vol. & $\%$ & Vol. & $\%$ & Vol. \\
\hline 1961 & 67 & 59 & 26 & 42 & 26 & 22 & 21 & 8 & 66 & 28 & 71 & 21 & 35 & 49 & 40 \\
\hline 1962-1963 & 54 & 26 & 4 & 3 & 60 & 22 & 17 & 29 & 3 & 68 & 57 & 3 & 63 & 76 & 51 \\
\hline
\end{tabular}

TABLE 4. Food items found in stomachs and intestines of Pahrump poolfish, 1961-1963. Items are grouped into 6 major categories

\begin{tabular}{lllll}
\hline Aquatic insects & Snails & Animal & Plant & Organic \\
\hline Insect & Pyrgulopsis deaconi & Flatworm & Stem & Fecal matter \\
Diptera & Tryonia sp. & Ostracod & Fibrous & Unident \\
Ephemeroptera & Gyraulis? & Cladocera & Seed & \\
Tricoptera & Physa? & Egg & & \\
Baetidae & & Fish scale & & \\
Argia & & & \\
Pelodytes & & & \\
Baetodes & & & \\
Stactobiella & & & \\
\hline
\end{tabular}

expanded its population from April to November 1976. The transplanted poolfish population in the variable-temperature reservoir at Spring Mountain Ranch State Park began spawning in June and continued through the summer (Selby 1977, LaVoie 2004). Baugh et al. (1988) demonstrated reproductive capability of Pahrump poolfish in laboratory aquaria in February-April. Their laboratory stock was taken from Corn Creek Spring, Clark County, Nevada.

Baugh et. al (1988) showed that sex ratios (M:F) for Pahrump poolfish in Corn Creek, an irrigation reservoir at Spring Mountain Ranch State Park, and Shoshone ponds were 1:3.5, 1:3, and 1:3.9, respectively. Both Selby (1977) and Baugh et al. (1988) noted that males tended to be smaller than females, and Williams (1986) reported seasonally variable but much less extreme, unbalanced sex ratios in another Nevada empetrichthyid, Crenichthys nevadae. While our collections were not made with a view toward determining sex ratio, there also was no effort made to collect either sex preferentially. The sex ratios of 1:19 for the 118 fish from which scales were taken and sex was determined and 1:11 for the 105 fish whose food habits were examined and sex was determined suggest an even more extreme female domination of the adult population in Manse Spring than was true in any of the more-variable-temperature habitats into which the species was transplanted. Sexual selection by traps, or inadvertent selection of larger, and therefore predominantly female, fish for preservation cannot be discounted.

\section{Reproductive Potential}

Increased poolfish mortality rate caused by the combined effects of goldfish and habitat disruption markedly reduced reproductive potential by reducing the number and/or proportion of larger, more-fecund females in the population. Size-class-related production of mature eggs (Table 5), applied to pre- and postgoldfish size class distributions (Figs. 2, 3), provides an estimate of the magnitude of this effect. The calculation suggests that, even with no reduction in population size, reproductive potential of the post-goldfish population would be about $32 \%$ of the pre-goldfish population. Subjecting results reported by Baugh et al. (1988) to the same analysis suggests an even more extreme post-goldfish reproductive potential at about $4 \%$ of the pre-goldfish level. A major portion of the difference originates from the fact that we defined a mature egg as one with a diameter $\geq 1.2 \mathrm{~mm}$ (Table 5), while Baugh et al. (1988) used a diameter $\geq 1.5 \mathrm{~mm}$ as their criterion. Using our criterion for mature eggs, the pre-goldfish population would be expected to produce approximately $85 \%$ of its mature eggs in April, with that percentage being reduced to $67 \%$ of the annual total following establishment 


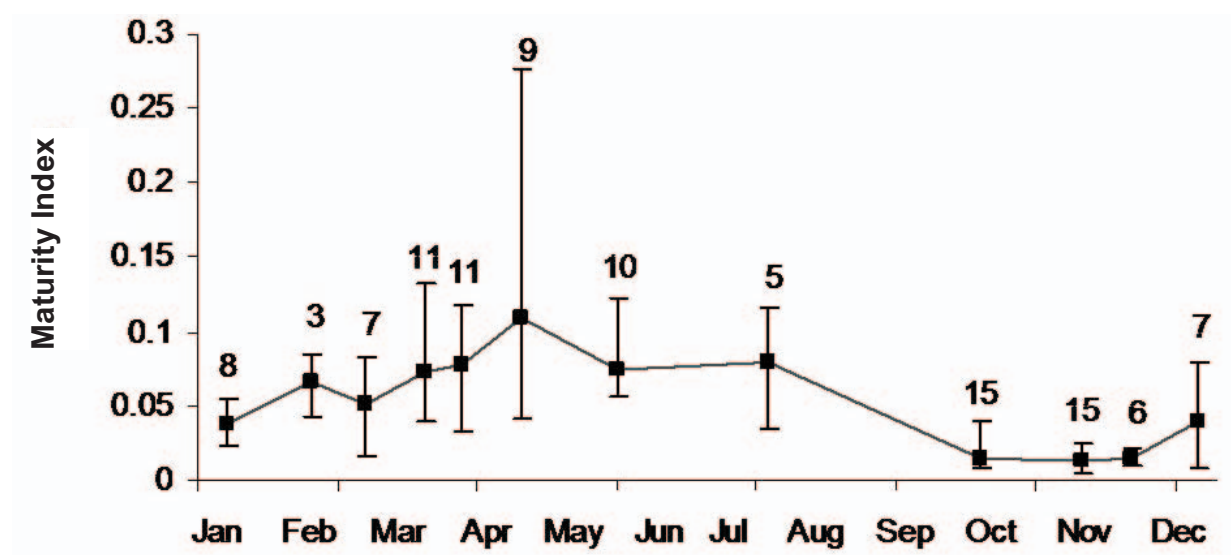

Fig. 4. Mean and range of maturity indices (ovary weight/body weight) of Pahrump poolfish from Manse Spring, Pahrump Valley, Nevada, October 1967 through July 1968 ( $n=107)$.

TABLE 5. Mean numbers of mature eggs produced by female poolfish in Manse Spring in April $(n=41)$ and during the off-season $(n=100)$, 1961-1965.

\begin{tabular}{lrcrcc}
\hline & \multicolumn{2}{c}{ April } & & \multicolumn{2}{c}{ Off-season } \\
\cline { 2 - 3 } \cline { 5 - 6 } SL & \multicolumn{1}{c}{$n$} & Eggs $(\bar{x})$ & & $n$ & Eggs $(\bar{x})$ \\
\hline $30-39$ & 3 & 19 & & 35 & 8 \\
$40-49$ & 22 & 33 & & 35 & 21 \\
$50-59$ & 9 & 63 & & 19 & 19 \\
$60-69$ & 7 & 111 & & 10 & 20 \\
$70-79$ & 0 & - & 1 & 43 \\
\hline
\end{tabular}

of goldfish. Using the Baugh et al. (1988) criterion, comparable percentages for April would drop from $94 \%$ to $50 \%$ of the annual total.

\section{Conclusion}

Poolfish in Manse Spring twice, in the presence of goldfish, experienced a population crash to $<50$ individuals followed by a recovery to more than 1000. The fact that the recovery occurred in the presence of a substantial goldfish population makes it illogical to attribute the crashes primarily to goldfish. Instead, the nearly identical patterns of crash and recovery following similar physical habitat disturbances (removal of submersed vegetation) by humans in 1962 and 1967 support a causative relationship between the crash and the habitat disruption associated with removal of vegetation. Habitat modification by humans and introduction of exotic species often occur simultaneously and are often cited as primary causes for population decline or extinction of native species (Deacon et al. 1964, Miller et al. 1989, Crivelli 1995, Minckley and Marsh 2009). While physical disturbances may be temporary (pulse disturbances), biological introductions are frequently permanent, or at least long term (press disturbances).

Shifts in life history characteristics of native species are also common following introductions (Courtenay and Stauffer 1984, McPeek and Peckarsky 1998, Altwegg 2002). The changes in poolfish life history characteristics reported here occurred soon after goldfish became established but appear to have persisted through 2 episodes of population crash and recovery. Goldfish are known to increase turbidity by feeding behavior that uproots aquatic vegetation (Richardson et al. 1995). They also transmit diseases and parasites (Wydoski and Whitney 2003), and compete for food and/or space (Brown and Moyle 1991). In this instance, soon after goldfish became established, the proportion of larger poolfish in the population declined, and poolfish $>60 \mathrm{~mm}$ SL were absent after January 1963. The implied increase in mortality rate revealed by this persistent change in poolfish population structure is also suggested by the increased frequency of annulus formation, absence of a fourth annulus after 1961, and a dietary shift from animals to plants. Reduction in the proportion of large females in the population caused a substantial reduction in fecundity, which nevertheless did not prevent recovery of the population. These chronic changes in poolfish life history can logically be attributed to persistent biological pressure from goldfish.

We conclude that, in this case, physical disruption of the habitat by humans was the 
primary cause of the poolfish population crashes. Persistent pressure from the goldfish population was the primary cause of changes in poolfish life history.

\section{ACKNOWLEDGMENTS}

We thank Walter R. Courtenay Jr., Mary Dale Deacon, Stanley V. Gregory, Austin E. Williams, Cindy Deacon Williams, Jack E. Williams, 2 anonymous reviewers for critical review of this paper, and Nelli Williams and Dave Melton for creative help with figures. Charles Ivy made numerous observations and measurements in the mid-1960s with the intention of using them as a basis for his master's thesis. Service in the Armed Forces interfered with completion of that thesis; however, his careful organization of the data left it in usable condition 4 decades later. Michael O'Farrell, Carol James, David Petty and other students and friends participated in data collection. Carl L. Hubbs, Robert R. Miller, graduate students from ASU under the direction of W.L. Minckley, students from UNLV, and Cindy Deacon Williams participated in the major effort to remove goldfish from Manse Spring in June and July 1967. Their contribution to the collection of data used in this paper is gratefully acknowledged. Doug Nelson, Collection Coordinator, University of Michigan Museum of Zoology (UMMZ) kindly provided information from Robert R. Miller's 1937 field collections deposited at UMMZ.

\section{Literature Cited}

AltweGG, R. 2002. Predator-induced life-history plasticity under time constraints in pool frogs. Ecology 83:25422551.

Baugh, T.M., J.E. Deacon, and P. FitzPatrick. 1988. Reproduction and growth of the Pahrump poolfish (Empetrichthys latos latos Miller) in the laboratory and nature. Journal of Aquariculture and Aquatic Sciences 5:1-5.

Brown, U.R., AND P.B. Moyle. 1991. Changes in habitat and microhabitat partitioning within an assemblage of stream fishes in response to predation by Sacramento squawfish Ptychocheilus grandis. Canadian Journal of Fisheries and Aquatic Sciences. 48:849856.

Courtenay, W.R., JR., And J.R. Stauffer JR. 1984. Distribution, biology, and management of exotic fishes. Johns Hopkins University Press. Baltimore and London. 430 pp.

Crivelli, A.J. 1995. Are fish introductions a threat to endemic freshwater fishes in the northern Mediterranean region? Biological Conservation 72:311-319.

DEACON, J.E. 1979. Endangered and threatened fishes of the West. Great Basin Naturalist Memoirs 3:41-64.
Deacon, J.E., C. Hubbs, and B. Zahuranec. 1964. Some effects of introduced fishes on the native fish fauna of southern Nevada. Copeia 1964:384-388.

Deacon, J.E., A.E. Williams, C.D. Williams, and J.E. WiLLiams. 2007. Fueling population growth in Las Vegas: how large-scale groundwater withdrawal could burn regional biodiversity. BioScience 57:688-698.

EsPINOSA, F.A. 1968. Spawning periodicity and fecundity of Crenichthys balileyi, a fish endemic to Nevada. Master's thesis, University of Nevada, Las Vegas, NV. 86 pp.

Hershler, R. 1998. A systematic review of the Hydrobiid snails (Gastropoda: Rissooidea) of the Great Basin, western United States. Part I: genus Pyrgulopsis. Veliger 41(1):1-132.

JENKIns, R.E., AND L.H. BuRKHEAD. 1993. Freshwater fishes of Virginia. American Fisheries Society, Bethesda, MD. $1079 \mathrm{pp}$.

LAKE, P.S. 2000. Disturbance, patchiness, and diversity in streams. Journal of the North American Benthological Society 19:573-592.

LAVoie, A. 2004. Endangered and threatened wildlife and plants; withdrawal of proposed rule to reclassify the Pahrump poolfish (Empetrichthys latos) from endangered to threatened status. Federal Register 69(64): 17383-17386.

Light, T., AND M.P. Marchetti. 2007. Distinguishing between invasion and habitat changes as drivers of diversity loss among California's freshwater fish. Conservation Biology 21:434-446.

McPeek, M.A., AND B.I. PeCKarsky. 1998. Life histories and the strengths of species interactions: combining mortality, growth, and fecundity effects. Ecology 79:867879 .

Miller, R.R., J.D. Williams, and J.E. Williams. 1989. Extinctions of North American fishes during the past century. Fisheries 14:22-38.

Minckley, W.L., AND J.E. DEACON. 1968. Southwestern fishes and the enigma of endangered species. Science 159:1424-1432.

MinCKLEY, W.L., AND P.C. MaRsh. 2009. Inland fishes of the greater Southwest. University of Arizona Press, Tucson, AZ. 426 pp.

Moyle, P.B. 2002. Inland fishes of California. Revised edition. University of California Press, Berkeley, CA. 517 pp.

RichaRdson, M.J., F.G. Whoriskey, and L.H. Roy. 1995. Turbidity generation and biological impacts of an exotic fish Carassius auratus, introduced into shallow seasonally anoxic ponds. Journal of Fish Biology 47: $576-585$.

Riggs, A.C., and J.E. Deacon. 2002. Connectivity in desert aquatic ecosystems: the Devils Hole story. Pages 1-38 in Conference proceedings-spring-fed wetlands: important scientific and cultural resources of the Intermountain Region. Available from: http://www .wetlands.dri.edu

SADA, D.W. 2008. Synecology of a springsnail (Caenogastropoda: Hydrobiidae) assemblage in a western U.S. thermal spring province. Veliger 50:59-71.

Scoppettone, G.G., P.H. Rissler, C. Gourley, and C. Martínez. 2005. Habitat restoration as a means of controlling non-native fish in a Mojave Desert oasis. Restoration Ecology 13:247-256.

SEAMAN, E.A. 1979. Observations on Carassius auratus (Linnaeus) harvesting Potomogeton foliosus Rafinesque in a small pond in northern Virginia. Fisheries 4:24-25. 
SELBY, D. 1977. Thermal ecology of the Pahrump killifish, Empetrichthys latos latos Miller. Master's thesis, University of Nevada, Las Vegas, NV. 55 pp.

SoLTZ, D.L., AND R.J. NAIMAN. 1978. The natural history of native fishes in the Death Valley system. Los Angeles (CA): Natural History Museum. Science Series 30: $1-76$.

Uyeno, T., and R.R. Miller. 1962. Relationships of Empetrichthys erdisi, a Pliocene cyprinodontid fish from California, with remarks on the Fundulinae and Cyprinodontinae. Copeia 1962:520-532.
Williams, C.D. 1986. Life history of the Railroad Valley springfish, Crenichthys nevadae Hubbs (Cyprinodontidae), of east-central Nevada. Master's thesis, California State University, Sacramento, CA. 124 pp.

WYDOSKI, R.S., AND R.R. WhitNEY. 2003. Inland fishes of Washington. 2nd edition. American Fisheries Society and University of Washington Press, Bethesda and Seattle, WA. 322 pp.

Received 27 December 2008 Accepted 2 August 2010 